\title{
Complete genome sequence of Thalassolituus oleivorans R6-15, an obligate hydrocarbonoclastic marine bacterium from the Arctic Ocean
}

\author{
Chunming Dong ${ }^{1,2,3 \dagger}$, Xin Chen $^{1,2,3,4 \dagger}$, Yanrong Xie ${ }^{1,2,3,4}$, Qiliang Lai ${ }^{1,2,3}$, Zongze Shao ${ }^{1,2,3^{*}}$ \\ ${ }^{1}$ Key Laboratory of Marine Genetic Resources, Third Institute of Oceanography, State Oce- \\ anic Administration, Xiamen, China; \\ ${ }^{2}$ State Key Laboratory Breeding Base of Marine Genetic Resources, Xiamen, China; \\ ${ }^{3}$ Key Laboratory of Marine Genetic Resources of Fujian Province, Xiamen, China; . \\ ${ }^{4}$ Life Science College, Xiamen University, Xiamen 361005, Fujian, China. \\ *Correspondence: Zongze Shao (shaozz@163.com) \\ ${ }^{\dagger}$ Authors contributed equally to this work.
}

Keywords: Thalassolituus, genome, alkane-degrading, surface seawater, Arctic Ocean

\begin{abstract}
Strain R6-15 belongs to the genus Thalassolituus, in the family Oceanospirillaceae of Gammaproteobacteria. Representatives of this genus are known to be the obligate hydrocarbonoclastic marine bacteria. Thalassolituus oleivorans R6-15 is of special interest due to its dominance in the crude oildegrading consortia enriched from the surface seawater of the Arctic Ocean. Here we describe the complete genome sequence and annotation of this strain, together with its phenotypic characteristics. The genome with size of 3,764,053 bp comprises one chromosome without any plasmids, and contains 3,372 protein-coding and 61 RNA genes, including 12 rRNA genes.
\end{abstract}

\section{Introduction}

Thalassolituus spp. belong to the Oceanospirillaceae of Gammaproteobacteria. The genus was first described by Yakimov et.al. (2004), and is currently composed of two type species, $T$. oleivorans and T. marinus [1,2]. Bacteria of this genus are known as obligate hydrocarbonoclastic marine bacteria [3]. Previous reports showed that Thalassolituusrelated species were among the most dominant members of the petroleum hydrocarbon-enriched consortia at low temperature [4-7]. In addition to consortia enriched with oil, Thalassolituus spp. can be detected in variety of cold environments as well [8-10].

Strain R6-15 was isolated from the surface seawater of the Arctic Ocean after enriched with crude oil during the fourth Chinese National Arctic Research Expedition of the "Xulong" icebreaker in the summer of 2010. The 16S rRNA gene sequence shared $99.86 \%$ and $96.39 \%$ similarities with $T$. oleivorans MIL-1 ${ }^{\mathrm{T}}$ and T. marinus IMCC1826 ${ }^{\mathrm{T}}$, respectively. Pyrosequencing results (16S rRNA gene V3 region) of fifteen oil-degrading consortia across the Arctic Ocean showed that the dominant member in most of the consortia shared identical sequence of this strain, comprising $8.4-99.6 \%$ of the total reads (not published).

Here, we described the complete genome sequence and annotation of strain T. oleivorans R615 , and its phenotypic characteristics. Moreover, a brief comparison was made between strain R6-15 and the two type strains of the validly named species of this genus, in both phenotypic and genomic aspects.

\section{Classification and features}

$T$. oleivorans R6-15 is closely related with $T$. oleivorans MIL-1 ${ }^{\mathrm{T}}$ (Figure 1, Table 1). The strain is aerobic, Gram-negative and motile by a single polar flagellum, exhibiting a characteristic morphology of a curved rod-shape cell (Figure 2). Strain R6-15 is able to utilize a restricted spectrum of carbon substrates for growth, including sodium acetate, Tween-40, Tween-80 and C12-C36 aliphatic hydrocarbons. Its growth temperature ranges from 4 to $32^{\circ} \mathrm{C}$ with optimum of $25^{\circ} \mathrm{C}$. 


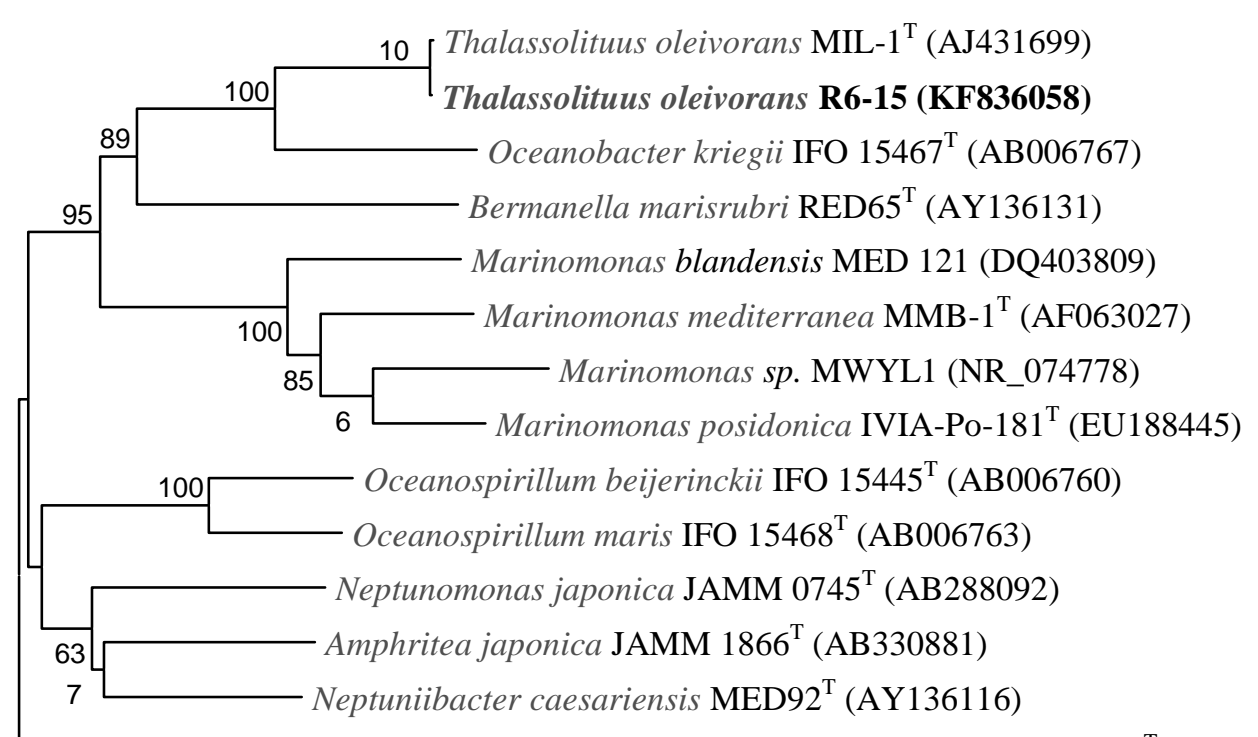

Marinospirillum minutulum ATCC $19193^{\mathrm{T}}$

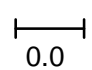

Figure 1. Phylogenetic tree highlighting the position of T. oleivorans strain R6-15 relative to other type and nontype strains with finished or non-contiguous finished genome sequences within the family Oceanospirillaceae. Accession numbers of $16 \mathrm{~S}$ rRNA gene sequences are indicated in brackets. Sequences were aligned using DNAMAN version 6.0, and a neighbor-joining tree obtained using the maximum-likelihood method within the MEGA version 5.0 [11]. Numbers adjacent to the branches represent percentage bootstrap values based on 1,000 replicates.

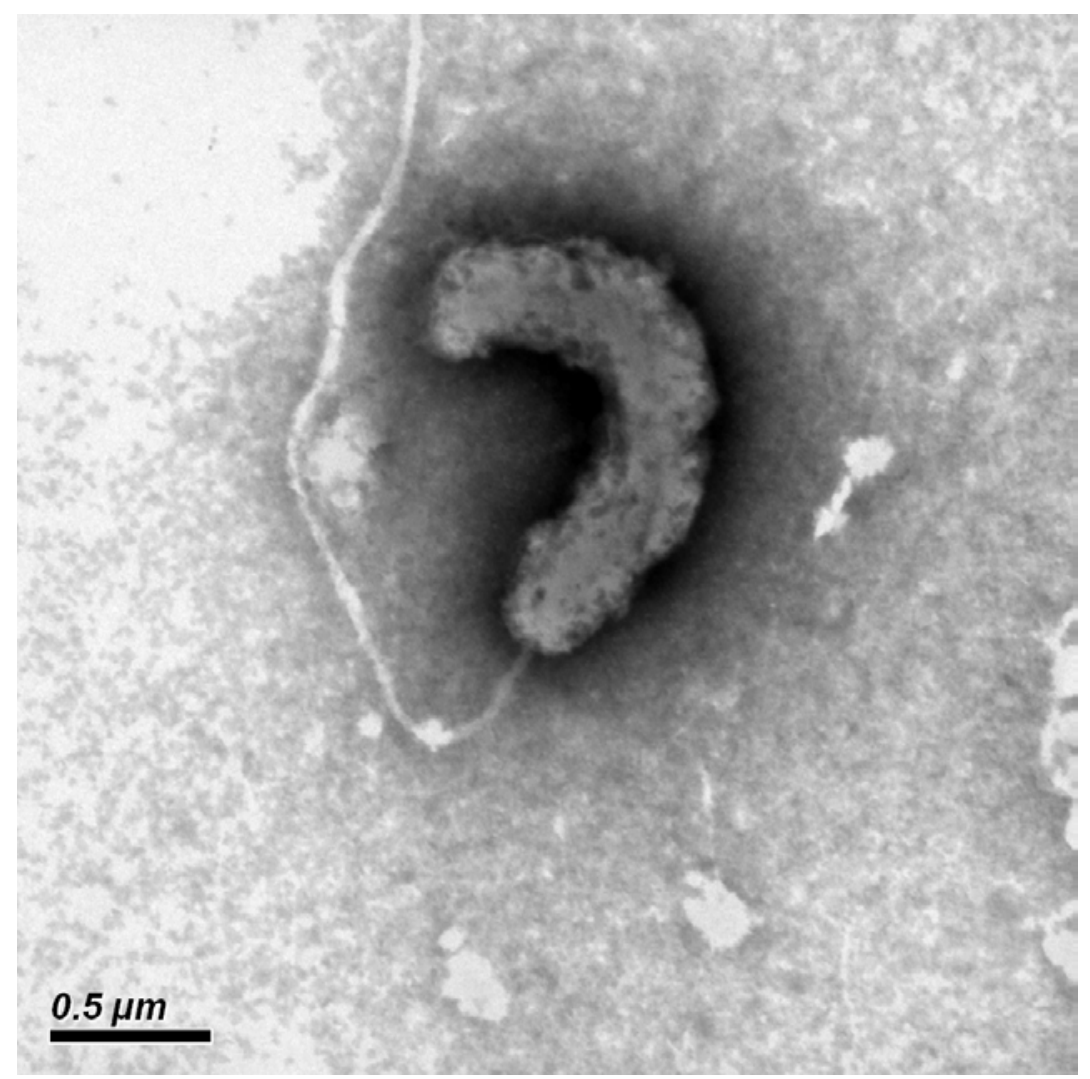

Figure 2. Transmission electron micrograph of T. oleivorans R6-15, using a JEM-1230 (JEOL) at an operating voltage of $120 \mathrm{kV}$. The scale bar represents $0.5 \mu \mathrm{m}$. 
Dong et al.

\begin{tabular}{|c|c|c|c|}
\hline MIGS ID & Property & Term & Evidence code $^{\mathrm{a}}$ \\
\hline & \multirow{7}{*}{ Current classification } & Domain Bacteria & TAS [13] \\
\hline & & Phylum Proteobacteria & TAS [14] \\
\hline & & Class Gammaproteobacteria & TAS [15-17] \\
\hline & & Order Oceanospirillales & TAS $[16,18]$ \\
\hline & & Family Oceanospirillaceae & $\operatorname{TAS}[16,19]$ \\
\hline & & Genus Thalassolituus & TAS [1] \\
\hline & & Species Thalassolituus oleivorans & IDA \\
\hline & Gram stain & Negative & IDA \\
\hline & Cell shape & Curved rods & IDA \\
\hline & Motility & Motile & IDA \\
\hline & Sporulation & Non-sporulating & IDA \\
\hline & Temperature range & $4-32^{\circ} \mathrm{C}$ & IDA \\
\hline & Optimum temperature & $25^{\circ} \mathrm{C}$ & IDA \\
\hline & Carbon source & $\begin{array}{l}\text { Sodium acetate, Tween-40, Tween-80, } \\
\text { alkanes (C12-C36) }\end{array}$ & IDA \\
\hline & Energy source & Chemoorganotrophic & IDA \\
\hline & Terminal electron receptor & Oxygen & IDA \\
\hline MIGS-6 & Habitat & Surface seawater & IDA \\
\hline MIGS-6.3 & Salinity & $0.5-5 \% \mathrm{NaCl}(\mathrm{w} / \mathrm{v})$ & IDA \\
\hline MIGS-22 & Oxygen & Aerobic & IDA \\
\hline MIGS-15 & Biotic relationship & Free-living & IDA \\
\hline MIGS-14 & Pathogenicity & Unknown & NAS \\
\hline MIGS-4 & Geographic location & Chukchi Sea, Arctic Ocean & IDA \\
\hline MIGS-5 & Sample collection time & July 2010 & IDA \\
\hline MIGS-4.1 & Latitude & $69^{\circ} 30.00^{\prime}$ & IDA \\
\hline MIGS-4.2 & Longitude & $-168^{\circ} 59.00^{\prime}$ & IDA \\
\hline MIGS-4.3 & Depth & Surface seawater & IDA \\
\hline MIGS-4.4 & Altitude & Sea level & IDA \\
\hline
\end{tabular}

a) Evidence codes - IDA: Inferred from Direct Assay; TAS: Traceable Author Statement (i.e., a direct report exists in the literature); NAS: Non-traceable Author Statement (i.e., not directly observed for the living, isolated sample, but based on a generally accepted property for the species, or anecdotal evidence). These evidence codes are from the Gene Ontology project [20]. If the evidence code is IDA, then the property should have been directly observed, for the purpose of this specific publication, for a live isolate by one of the authors, or an expert or reputable institution mentioned in the acknowledgements.

When compared to other Thalassolituus species, strain R6-15 differed from type strain MIL-1 ${ }^{\mathrm{T}}$ [1] in catalase, urease and acid phosphatase, and in the utilization of $n$-alkane, pyruvic acid methyl ester, D-mannitol and D-sorbitol (Table 2). Differences were also observed with type strain
IMCC1826 ${ }^{\mathrm{T}}$ [2] in growth temperature range, catalase, nitrate reductase, urease and leucine arylamidase and the utilization of n-alkane, pyruvic acid methyl ester, $\beta$-Hydroxybutyric acid and D,LLactic acid (Table 2). 
Table 2. Differential phenotypic characteristics between T. oleivorans R6-15 and other Thalassolituus species.

\begin{tabular}{|c|c|c|c|}
\hline Characteristic & 1 & 2 & 3 \\
\hline Cell diameter $(\mu \mathrm{m})$ & $0.25-0.4 \times 1.2-2.0$ & $0.32-0.77 \times 1.2-3.1$ & $0.4-0.5 \times 1.2-2.5$ \\
\hline Salinity/Optimum (w/v) & $0.5-5 \% / 3 \%$ & $0.5-5.7 \% / 2.3 \%$ & $0.5-5.0 \% / 2.5 \%$ \\
\hline Temperature range $\left({ }^{\circ} \mathrm{C}\right)$ & $4-32$ & $4-30$ & $15-42$ \\
\hline Number of polar flagella & 1 & $1-4$ & 1 \\
\hline \multicolumn{4}{|l|}{$\underline{\text { Production of }}$} \\
\hline Catalase & - & + & + \\
\hline Nitrate reductase & - & - & + \\
\hline Urease & $\mathrm{w}$ & - & + \\
\hline Acid phosphatase & + & - & + \\
\hline Leucine arylamidase & + & + & - \\
\hline \multicolumn{4}{|l|}{ Carbon source } \\
\hline Sodium acetate & + & + & na \\
\hline n-alkane & $\mathrm{C} 12-\mathrm{C} 36$ & $\mathrm{C} 7-\mathrm{C} 20$ & $\mathrm{C} 14$ and $\mathrm{C} 16$ \\
\hline Pyruvic acid methyl ester & w & - & + \\
\hline$\beta$-Hydroxybutyric acid & - & - & + \\
\hline D,L-Lactic acid & - & - & + \\
\hline D-Mannitol & - & + & - \\
\hline D-Sorbitol & - & + & - \\
\hline Geographic location & $\begin{array}{l}\text { Chukchi Sea, } \\
\text { Arctic Ocean }\end{array}$ & $\begin{array}{r}\text { Harbor of Milazzo, } \\
\text { Italy }\end{array}$ & $\begin{array}{r}\text { Deokjeok island, Ko- } \\
\text { rea }\end{array}$ \\
\hline Habitat & surface seawater & seawater/sediment & surface seawater \\
\hline $\mathrm{G}+\mathrm{C}$ content (mol\%) & 46.6 & 46.6 & 54.6 \\
\hline
\end{tabular}

Strains: 1, T. oleivorans R6-15; 2, T. oleivorans MIL-1 ${ }^{\mathrm{T}} ; 3$, T. marinus IMCC $1826^{\mathrm{T}}$. +: positive result, -: negative result, w: weak positive result, na: data not available.

\section{Genome sequencing information}

\section{Genome project history}

This organism was selected for sequencing on the basis of its phylogenetic position and dominance position in the crude oil-degrading consortia enriched from the surface seawater of the Arctic Ocean. The complete genome sequence was deposited in Genbank under accession number
CP006829. Sequencing, finishing and annotation of the T. oleivorans R6-15 genome were performed by the Chinese National Human Genome Center (Shanghai). Table 3 presents the project information and its association with MIGS version 2.0 compliance [21].

Table 3. Project information

\begin{tabular}{lll}
\hline MIGS ID & Property & Term \\
\hline MIGS-31 & Finishing quality & Finished \\
MIGS-28 & Libraries used & one 454 pyrosequence standard library \\
MIGS-29 & Sequencing platforms & 454 GS FLX Titanium \\
MIGS-31.2 & Fold coverage & $21.1 \times$ \\
MIGS-30 & Assemblers & Newbler version 2.7 \\
MIGS-32 & Gene calling method & NCBI PGAP pipeline \\
& GenBank ID & CP006829 \\
& GenBank Date of Release & On publication \\
& GoLD ID & Gi20060 \\
& Project relevance & Crude oil-degradation, biogeography \\
\hline
\end{tabular}




\section{Growth conditions and DNA isolation}

Strain R6-15 was grown aerobically in ONR7a medium [22] with sodium acetate as the sole carbon and energy source. The genomic DNA was extracted from the cell, concentrated and purified using the AxyPrep bacterial genomic DNA miniprep Kit (Axygen), as detailed in the manual for the instrument.

\section{Genome sequencing and assembly}

The genome was sequenced by using a massively parallel pyrosequencing technology (454 GS FLX) [23]. A total of 140,550 reads counting up to $78,223,504$ bases were obtained, covered 21.1folds of genome. The Newbler V2.7 [24] software package was used for sequence assembly and quality assessment. After assembling, 64 contigs ranging from $500 \mathrm{bp}$ to $304,980 \mathrm{bp}$ were obtained, and the relationship of the contigs was determined by multiplex PCR [25]. Gaps were then filled in by sequencing the PCR products using ABI $3730 x l$ capillary sequencers. A total of 284 additional reactions were necessary to close gaps and to raise the quality of the finished sequence. Finally, the sequences were assembled using Phred, Phrap and Consed software packages [26], and low quality regions of the genome were resequenced. The final sequence accuracy was approximately $99.999 \%$.

\section{Genome annotation}

The protein-coding genes, structural RNAs (5S, 16S, 23S), tRNAs and small non-coding RNAs were predicted and achieved by using the NCBI Prokaryotic Genome Annotation Pipeline (PGAP) server online [27]. The functional annotation of predicted ORFs was performed using RPS-BLAST [28] against the cluster of orthologous groups (COG) database [29] and Pfam database [30]. TMHMM program was used for gene prediction with transmembrane helices [31] and signalP program was used for prediction of genes with peptide signals [32].

\section{Genome properties}

The properties and the statistics of the genome are summarized in Table 4. The genome includes one circular chromosome of 3,764,053 bp (46.6\% GC content). In total, 3,489 genes were predicted, 3,372 of which are protein-coding genes, and 61 RNAs; 56 pseudogenes were also identified. The majority of the protein-coding genes (67.07\%) were assigned a putative function while the remaining ones were annotated as hypothetical proteins. The distribution of genes into COGs functional categories is presented in Table 5 and Figure 3.

Table 4. Genome statistics

\begin{tabular}{lrr}
\hline Attribute & Value & \% of Total $^{\mathbf{a}}$ \\
\hline Genome size (bp) & $3,764,053$ & 100.0 \\
DNA coding region (bp) & $3,315,444$ & 88.08 \\
DNA G+C content (bp) & $1,753,947$ & 46.60 \\
Number of replicons & 1 & \\
Extrachromosomal elements & 0 & 100.00 \\
Total genes & 3,489 & 1.75 \\
RNA genes & 61 & 1.38 \\
tRNA genes & 48 & 0.03 \\
rRNA operons & 4 & 96.65 \\
ncRNA genes & 1 & 1.61 \\
Protein-coding genes & 3,372 & 67.07 \\
Pseudo genes & 56 & 30.12 \\
Genes with function prediction & 2,340 & 64.46 \\
Genes in paralog clusters & 1,051 & 73.83 \\
Genes assigned to CoGs & 2,249 & 9.69 \\
Genes assigned Pfam domains & 2,576 & 22.21 \\
Genes with signal peptides & 338 & 775 \\
Genes with transmembrane helices & & \\
\hline
\end{tabular}

${ }^{a}$ The total is based on either the size of the genome in base pairs or on the total number of protein coding genes in the annotated genome. 


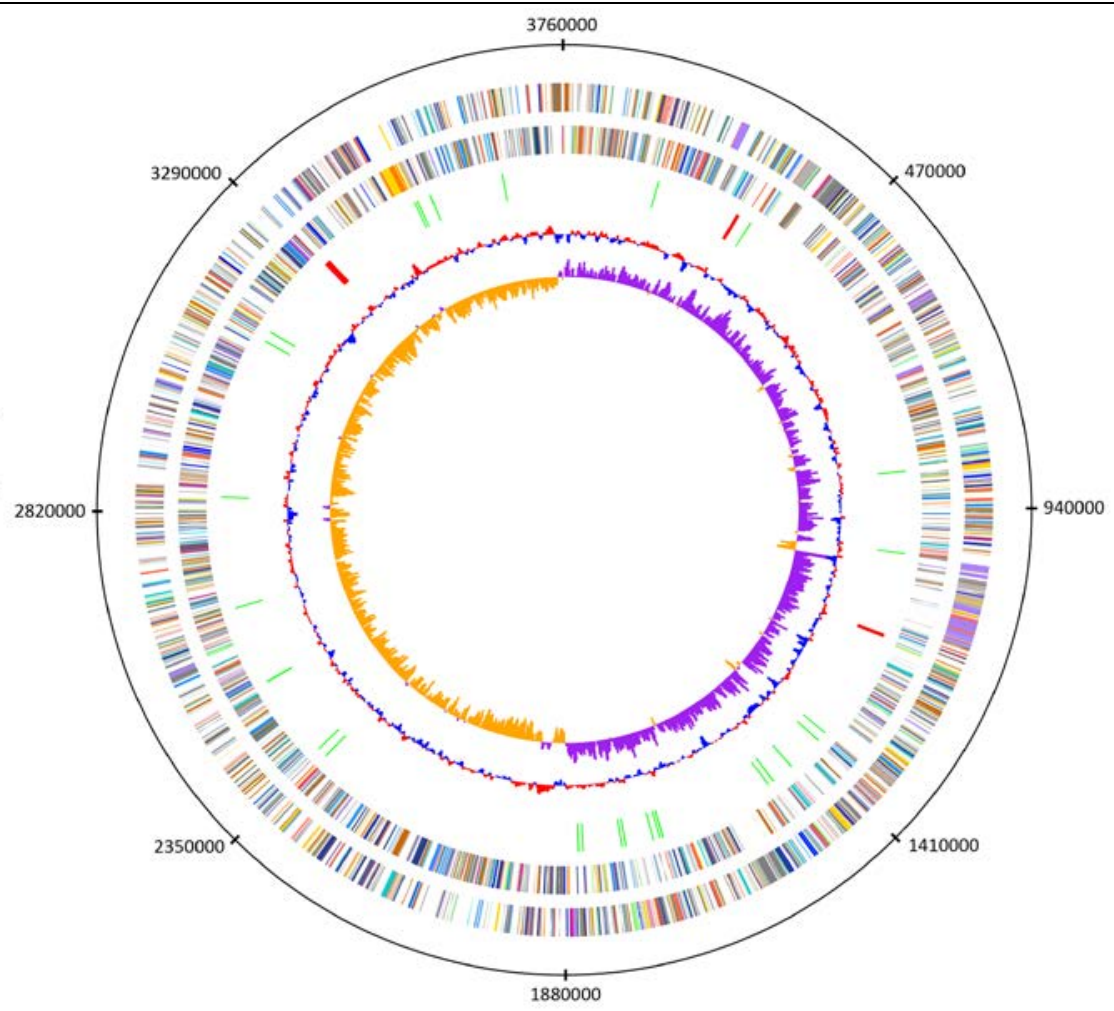

Figure 3. Graphical map of the chromosome. From outside to the center: Genes on forward strand (color by COG categories), genes on reverse strand (color by COG categories), RNA genes (tRNAs green, rRNAs red), GC content, GC skew.

Table 5. Number of genes associated with the 25 general COG functional categories

\begin{tabular}{crrl}
\hline Code & Value & \%age & \multicolumn{1}{c}{ Description } \\
\hline J & 182 & 7.11 & Translation, ribosomal structure and biogenesis \\
A & 1 & 0.04 & RNA processing and modification \\
K & 161 & 6.29 & Transcription \\
L & 5.16 & Replication, recombination and repair \\
B & 132 & 0.04 & Chromatin structure and dynamics \\
D & 1 & 1.25 & Cell cycle control, cell division, chromosome partitioning \\
Y & 32 & 0.00 & Nuclear structure \\
V & 0 & 1.09 & Defense mechanisms \\
T & 28 & 5.94 & Signal transduction mechanisms \\
M & 152 & 5.86 & Cell wall/membrane/envelope biogenesis \\
N & 150 & 0.32 & Cell motility \\
Z & 85 & 0.00 & Cytoskeleton \\
W & 1 & 3.24 & Intracellular structures trafficking, secretion, and vesicular transport \\
U & 0 & 4.96 & Posttranslational modification, protein turnover, chaperones \\
O & 83 & 59 & Energy production and conversion \\
C & 127 & 2.97 & Carbohydrate transport and metabolism \\
G & 143 & 7.30 & Amino acid transport and metabolism \\
E & 76 & 2.62 & Nucleotide transport and metabolism \\
F & 187 & 4.49 & Coenzyme transport and metabolism \\
H & 67 & 4.14 & Lipid transport and metabolism \\
I & 115 & 5.39 & Inorganic ion transport and metabolism \\
P & 106 & Secondary metabolites biosynthesis, transport and catabolism \\
Q & 138 & 8.85 & General function prediction only \\
R & 57 & Function unknown \\
S & 329 & 35.54 & Not in coGs \\
- & 207 & &
\end{tabular}


Dong et al.

\section{Insights from the genome sequence}

Until now, only the genome sequence of the type strain T. oleivorans MIL-1 ${ }^{\mathrm{T}}$ was available within the genus of Thalassolituus [9]. Here, we compared the genome of strain R6-15 with strain MIL$1^{\mathrm{T}}$ (Table 6). The genome of strain R6-15 is nearly $156 \mathrm{~kb}$ smaller in size than strain MIL-1 ${ }^{\mathrm{T}}$. The $\mathrm{G}+\mathrm{C}$ content of strain R6-15 (46.6\%) is similar with type strain MIL-1 ${ }^{\mathrm{T}}(46.6 \%)$. The gene content of strain R6-15 is smaller than strain MIL-1 ${ }^{\mathrm{T}}(3,489$ vs 3,732 ).

Strain R6-15 shares 2,995 orthologous genes with type strain MIL-1 ${ }^{\mathrm{T}}$. The average percentage of nu- cleotide sequence identity is $96.92 \%$ between strain R6-15 and MIL-1 ${ }^{\mathrm{T}}$. In addition, DNA-DNA hybridization (DDH) estimate value between strain R6-15 and MIL-1 ${ }^{\mathrm{T}}$ were calculated using the genome-to-genome distance calculator (GGDC2.0) $[33,34]$. The DDH estimate value between them was $84.5 \% \pm 2.57$, which were above the standard criteria (70\%) [35]. Therefore, these results confirmed that strain R6-15 belonged to the species of Thalassolituus oleivorans.

\begin{tabular}{|c|c|c|c|c|c|c|c|}
\hline $\begin{array}{l}\text { Genome } \\
\text { Name }\end{array}$ & $\begin{array}{l}\text { Genome } \\
\text { size (bp) }\end{array}$ & $\begin{array}{l}\text { Gene } \\
\text { count }\end{array}$ & $\begin{array}{l}\text { Pro- } \\
\text { tein } \\
\text { coding }\end{array}$ & $\begin{array}{l}\text { Protein } \\
\text { with } \\
\text { function }\end{array}$ & $\begin{array}{l}\text { Without } \\
\text { function }\end{array}$ & $\begin{array}{l}\text { Plasmid } \\
\text { number }\end{array}$ & $\begin{array}{l}\text { rRNA } \\
\text { operons }\end{array}$ \\
\hline T. oleivorans & & & & & & & \\
\hline $\begin{array}{l}\text { R6-15 } \\
\text { T. oleivorans }\end{array}$ & $3,764,053$ & 3,489 & 3,372 & 2,340 & 1,032 & 0 & 4 \\
\hline MIL-1 ${ }^{\mathrm{T}}$ & $3,920,328$ & 3,732 & 3,603 & 2,038 & 1,565 & 0 & 4 \\
\hline
\end{tabular}

Table 6. Comparison of genomes between T. oleivorans R6-15 and T. oleivorans MIL-1

\section{Conclusion}

Strain R6-15 is the first strain with the complete genome sequence of the genus Thalassolituus isolated from the Arctic Ocean. These genomic data will provide insights into the mechanisms of how this bacterium can thrive on the crude oil in the polar marine environments.

\section{References}

1. Yakimov MM, Giuliano L, Denaro R, Crisafi E, Chernikova TN, Abraham WR, Luensdorf H, Timmis KN, Golyshin PN. Thalassolituus oleivorans gen. nov., sp. nov., a novel marine bacterium that obligately utilizes hydrocarbons. Int J Syst Evol Microbiol 2004; 54:141-148. PubMed http://dx.doi.org/10.1099/ijs.0.02424-0

2. Choi A, Cho JC. Thalassolituus marinus sp. nov., a hydrocarbon-utilizing marine bacterium. Int J Syst Evol Microbiol 2013; 63:2234-2238. PubMed http://dx.doi.org/10.1099/ijs.0.046383-0

3. Yakimov MM, Timmis KN, Golyshin PN. Obligate oildegrading marine bacteria. Curr Opin Biotechnol 2007; 18:257-266. PubMed http://dx.doi.org/10.1016/j.copbio.2007.04.006

4. Yakimov MM, Denaro R, Genovese M, Cappello S, D'Auria G, Chernikova TN, Timmis KN, Golyshin PN, Giluliano L. Natural microbial diversity in superficial sediments of Milazzo Harbor (Sicily) and community successions during microcosm enrichment with various hydrocarbons. Environ Microbiol 2005; 7:1426-

\section{Acknowledgements}

This work was financially supported by the National Natural Science Foundation of China (41206158), the China Polar Environment Investigation and Estimate Project (2012-2015), and the Young Marine Science Foundation of SOA (2012142).

1441. PubMed http://dx.doi.org/10.1111/j.14625822.2005.00829.x

5. Coulon F, McKew BA, Osborn AM, McGenity TJ, Timmis KN. Effects of temperature and biostimulation on oil-degrading microbial communities in temperate estuarine waters. Environ Microbiol 2007; 9:177-186. PubMed http://dx.doi.org/10.1111/j.14622920.2006.01126.X

6. McKew BA, Coulon F, Osborn AM, Timmis KN, McGenity TJ. Determining the identity and roles of oil-metabolizing marine bacteria from the Thames estuary, UK. Environ Microbiol 2007; 9:165-176. PubMed

http://dx.doi.org/10.1111/j.14622920.2006.01125.x

7. McKew BA, Coulon F, Yakimov MM, Denaro R, Genovese M, Smith CJ, Osborn AM, Timmis KN, McGenity TJ. Efficacy of intervention strategies for bioremediation of crude oil in marine systems and effects on indigenous hydrocarbonoclastic bacteria. Environ Microbiol 2007; 9:1562-1571. PubMed http://dx.doi.org/10.1111/j.1462-2920.2007.01277.x 
8. Yakimov MM, Genovese M, Denaro R. Thalassolituus. Handbook of Hydrocarbon and Lipid Microbiology. Heidelberg: Springer-Verlag; 2010.

9. Golyshin PN, Werner J, Chernikova TN, Tran H, Ferrer M, Yakimov MM, Teeling H, Golyshina OV, Consortium MS. Genome Sequence of Thalassolituus oleivorans MIL-1 (DSM 14913T). Genome Announc 2013;1(2).

10. Hazen TC, Dubinsky EA, DeSantis TZ, Andersen GL, Piceno YM, Singh N, Jansson JK, Probst A, Borglin SE, Fortney JL, et al. Deep-sea oil plume enriches indigenous oil-degrading bacteria. Science 2010; 330:204208. PubMed http://dx.doi.org/10.1126/science.1195979

11. Tamura K, Peterson D, Peterson N, Stecher G, Nei M, Kumar S. MEGA5: molecular evolutionary genetics analysis using maximum likelihood, evolutionary distance, and maximum parsimony methods. Mol Biol Evol 2011; 28:2731-2739. PubMed http://dx.doi.org/10.1093/molbev/msr121

12. Field D, Garrity G, Gray T, Morrison N, Selengut J, Sterk P, Tatusova T, Thomson N, Allen MJ, Angiuoli $\mathrm{SV}$, et al. The minimum information about a genome sequence (MIGS) specification. Nat Biotechnol 2008; 26:541-547. PubMed http://dx.doi.org/10.1038/nbt1360

13. Woese CR, Kandler O, Wheelis ML. Towards a natural system of organisms: proposal for the domains Archaea, Bacteria, and Eucarya. Proc Natl Acad Sci USA 1990; 87:4576-4579. PubMed http://dx.doi.org/10.1073/pnas.87.12.4576

14. Garrity G, Bell J, Lilburn T. Phylum XIV. Proteobacteria phyl. nov. In: Garrity G, Brenner D, Krieg N, Staley J, editors. Bergey's Manual of Systematic Bacteriology. Second ed. Volume 2, Part B. New York: Springer; 2005. p 1.

15. Garrity G, Bell J, Lilburn T. Class III. Gammaproteobacteria class nov. In: Garrity G, Brenner D, Krieg N, Staley J, editors. Bergey's Manual of Systematic Bacteriology. Second ed. Volume 2, Part B. New York: Springer; 2005. p 1.

16. Validation of publication of new names and new combinations previously effectively published outside the IJSEM. List no. 106. Int J Syst Evol Microbiol 2005; 55:2235-2238. http://dx.doi.org/10.1099/ijs.0.64108-0

17. Williams KP, Kelly DP. Proposal for a new class within the phylum Proteobacteria,Acidithiobacillia classis nov., with the type order Acidithiobacillales, and emended description of the class Gammaproteobacteria. Int J Syst Evol Microbiol 2013; 63:2901-2906. PubMed http://dx.doi.org/10.1099/ijs.0.049270-0

18. Garrity G, Bell J, Lilburn T. Order VIII. Oceanospirillales ord. nov. In: Garrity G, Brenner D, Krieg N, Staley J, editors. Bergey's Manual of Systematic Bac- teriology. Second ed. Volume 2, Part B. New York: Springer; 2005. p 270.

19. Garrity G, Bell J, Lilburn T. Family I. Oceanospirillaceae fam. nov. In: Garrity G, Brenner D, Krieg N, Staley J, editors. Bergey's Manual of Systematic Bacteriology. Second ed. Volume 2, Part B. New York: Springer; 2005. p 271.

20. Ashburner M, Ball CA, Blake JA, Botstein D, Butler H, Cherry JM, Davis AP, Dolinski K, Dwight SS, Eppig JT, et al. Gene ontology: tool for the unification of biology. The Gene Ontology Consortium. Nat Genet 2000; 25:25-29. PubMed http://dx.doi.org/10.1038/75556

21. Field D, Garrity G, Gray T, Morrison N, Selengut J, Sterk P, Tatusova T, Thomson N, Allen MJ, Angiuoli $\mathrm{SV}$, et al. The minimum information about a genome sequence (MIGS) specification. Nat Biotechnol 2008; 26:541-547. PubMed http://dx.doi.org/10.1038/nbt1360

22. Dyksterhouse SE, Gray JP, Herwig RP, Lara JC, Staley JT. Cycloclasticus pugetii gen. nov., sp. nov., an aromatic hydrocarbon-degrading bacterium from marine sediments. Int J Syst Bacteriol 1995; 45:116-123. PubMed http://dx.doi.org/10.1099/00207713-45-1$\underline{116}$

23. Margulies M, Egholm M, Altman WE, Attiya S, Bader JS, Bemben LA, Berka J, Braverman MS, Chen YJ, Chen $Z$, et al. Genome sequencing in microfabricated high-density picolitre reactors. Nature 2005; 437:376-380. PubMed

24. The Newbler V2. 7. http://www.454.com/

25. Tettelin H, Radune D, Kasif S, Khouri H, Salzberg SL. Optimized multiplex PCR: efficiently closing a whole-genome shotgun sequencing project. Genomics 1999; 62:500-507. PubMed http://dx.doi.org/10.1006/geno.1999.6048

26. Phred, Phrap and Consed software packages. http://www.genome.washington.edu

27. Angiuoli SV, Gussman A, Klimke W, Cochrane G, Field D, Garrity G, Kodira CD, Kyrpides N, Madupu R, Markowitz V, et al. Toward an online repository of Standard Operating Procedures (SOPs) for (meta)genomic annotation. OMICS 2008; 12:137-141. PubMed http://dx.doi.org/10.1089/omi.2008.0017

28. Marchler-Bauer A, Anderson JB, Derbyshire MK, DeWeese-Scott C, Gonzales NR, Gwadz M, Hao L, He S, Hurwitz DI, Jackson JD, et al. CDD: a conserved domain database for interactive domain family analysis. Nucleic Acids Res 2007; 35:D237-D240. PubMed http://dx.doi.org/10.1093/nar/gkl951

29. Tatusov RL, Galperin MY, Natale DA, Koonin EV. The COG database: a tool for genome-scale analysis of protein functions and evolution. Nucleic Acids Res 2000; 28:33-36. PubMed http://dx.doi.org/10.1093/nar/28.1.33 
Dong et al.

30. Sonnhammer EL, Eddy SR, Durbin R. Pfam: a comprehensive database of protein domain families based on seed alignments. Proteins 1997; 28:405-420. PubMed http://dx.doi.org/10.1002/(SICI)10970134(199707)28:3<405::AID-PROT10>3.0.CO;2-L

31. Krogh A, Larsson B, von Heijne G, Sonnhammer EL. Predicting transmembrane protein topology with a hidden Markov model: application to complete genomes. J Mol Biol 2001; 305:567-580.
PubMed http://dx.doi.org/10.1006/jmbi.2000.4315

32. Bendtsen JD, Nielsen H, von Heijne G, Brunak S. Improved prediction of signal peptides: SignalP 3.0. J Mol Biol 2004; 340:783-795. PubMed http://dx.doi.org/10.1016/j.jmb.2004.05.028

33. Auch AF, Klenk HP, Goker M. Standard operating procedure for calculating genome-to-genome distances based on high-scoring segment pairs. Stand Genomic Sci 2010; 2:142-148. PubMed http://dx.doi.org/10.4056/sigs.541628

34. Auch AF, von Jan M, Klenk HP, Goker M. Digital DNA-DNA hybridization for microbial species delineation by means of genome-to-genome sequence comparison. Stand Genomic Sci 2010; 2:117-134. PubMed http://dx.doi.org/10.4056/sigs.531120

35. Wayne LG, Brenner DJ, Colwell RR, Grimont PAD, Kandler O, Krichevsky MI, Moore LH, Moore WEC, Murray RGE, Stackebrandt E, et al. Report of the Ad Hoc Committee on Reconciliation of Approaches to Bacterial Systematics. Int J Syst Bacteriol 1987; 37:463464. http://dx.doi.org/10.1099/00207713-37-4-463 